\title{
Dead Embryos despite Low Contaminant Loads in Eggs of Eleonora's Falcon
}

\author{
Marion Gschweng, ${ }^{1}$ Frieda Tataruch, ${ }^{2}$ Otmar Fröhlich, ${ }^{3}$ and Elisabeth K. V. Kalko, ${ }^{1,4}$ \\ ${ }^{1}$ Institute of Experimental Ecology, Ulm University, 89069 Ulm, Germany \\ ${ }^{2}$ Research Institute of Wildlife Ecology, University of Veterinary Medicine Vienna, 1160 Vienna, Austria \\ ${ }^{3}$ State Institute for Chemical and Veterinary Analysis of Food, 79114 Freiburg, Germany \\ ${ }^{4}$ Smithsonian Tropical Research Institute, Balboa, Ancón 03092, Panama \\ Correspondence should be addressed to Marion Gschweng, marion.gschweng@uni-ulm.de
}

Received 17 January 2011; Accepted 7 March 2011

Academic Editors: J. Joachim and I. Krams

Copyright ( $) 2011$ Marion Gschweng et al. This is an open access article distributed under the Creative Commons Attribution License, which permits unrestricted use, distribution, and reproduction in any medium, provided the original work is properly cited.

\begin{abstract}
As a long-distance migrant which crosses more than 20 African countries, Eleonora's Falcons might have experienced a substantial accumulation of contaminants when returning to their breeding grounds. In 2004 and 2005, we collected 21 failed eggs from two colonies on Sardinia, Italy. We found a high percentage of dead embryos and suspected this was due to a high contaminant load. Despite this, the overall values for the contaminants analysed were rather low and lay within the range found in other raptor species. We analysed the eggs for residues of DDT ( $\mathrm{p}, \mathrm{p}^{\prime}$-dichlorodiphenyltrichloroethane), PCB (polychlorinated biphenyl), and heavy metals. Although infertile eggs seem to be correlated with the highest values of $\sum$ DDT, we did not find substantial values of any of the contaminants investigated. Because of the low world population of the species and varying reproduction rates in the colonies ranging from Cyprus to the Canaries, we highly recommend further censuses of the reproductive success of Eleonora's Falcon, including the examination of failed eggs.
\end{abstract}

\section{Introduction}

Eleonora's Falcon (Falco eleonorae) has a restricted breeding range across the Mediterranean Sea and the adjoining part of the Atlantic. This rare, colonially breeding falcon has an estimated world population of only 15,300 breeding pairs [1]. Censuses have revealed that the breeding population of Eleonora's Falcon has undergone a moderate decline of more than $10 \%$ since the 1990 s [1]. This rate might be well within the range of a natural flux, but, regarding the overall small population, this decline should be carefully monitored in the coming years.

According to studies in previous years, the reproduction rate of Eleonora's Falcon varies substantially across its range. The highest rate has been measured in Morocco, where each breeding pair produced on average 2.6 offspring per year [2]. The lowest reproduction rate was documented in a colony on Cyprus with only 0.8 offspring per breeding pair per year [3]. Interestingly, this rate has remained stable at this low level over the years (Ristow, personal communication). Without incoming new breeding pairs, that is, offspring from other colonies, a reproduction rate as low as that on Cyprus is likely to further accelerate the present population decline [1].

During fieldwork at the breeding sites of Eleonora's Falcon from 2003 to 2005 [4], we found a high number of dead eggs left in the eyries. Because of the use of pesticides in African countries [5, 6], the spraying of DDT in the wintering area of Eleonora's Falcon in Madagascar between 1997 and 2000 [6] and the enormous locust outbreak in 2003 in North and West Africa, which was fought with the aerial spraying of pesticides, we suspected that the dead eggs would show a relatively high pesticide burden. With our study, we did not intend to find coherence between the contaminant load of the mother bird and its eggs but rather to find an answer on whether contaminants lead to the dead eggs found and whether the high percentage of dead embryos was related to contaminants at all. We, thus, adopted a correlative approach and assessed the pesticide burden of failed eggs of 
Eleonora's Falcon and investigated both the most common pesticides and heavy metals.

\section{Material and Methods}

2.1. Study Sites and Censuses. Fieldwork was conducted in two colonies on Sardinia. One colony comprises approximately 120 breeding pairs in rocky cliffs along $6 \mathrm{~km}$ of coastline on San Pietro, an inhabited island (ca. 6,000 inhabitants) off the southwest coast of mainland Sardinia. The second colony is located on the southernmost island of Sardinia, the uninhabited islet of Toro. Located $20 \mathrm{~km}$ west of Cape Teulada, it comprises approximately $50-70$ breeding pairs over a surface area of about 11 hectares [7].

From 2003 to 2005, we visited only easily accessible nest sites to count nestlings and eggs and to ring the young. Because of the high risk of disturbing the colony, independent sampling could not be executed, so our results might reflect a bias towards easily accessible nest sites.

We determined locations of nest sites with hand-held GPS receivers (Garmin eTrex Summit HC). The census on 21-23 September was done by systematically walking horizontal transects, while one licensed ringer switched back and forth between three groups comprising two people each to ring and weigh the nestlings.

In 2004, we took two unhatched eggs from two nests on Toro Island (14.09.04). In 2005, we sampled 18 unhatched eggs from 17 nests on Toro Island (22.09.05), and one from San Pietro Island (21.09.05). Most of the eggs $(n=19)$ were from nests with nestlings in the same brood, and only two eggs were taken together from a nest that had been abandoned. Both samples from this same nest are treated independently, as our goal was to see whether contaminants were responsible for the dead embryos at all without drawing conclusions on the contaminant load of the mother bird.

After egg collection and transport to Germany, samples were stored deep frozen at $-20^{\circ} \mathrm{C}$.

2.2. Chemical Analyses. 20 of the 21 eggs (2004: $n=2$; 2005: $n=19$ ) were used for analyses of organochlorines (OC). One egg was completely desiccated because of a cracked shell and was, therefore, excluded from the analysis. Each egg sample was tested for eleven substances comprising organochlorine pesticides, in particular $\mathrm{p}, \mathrm{p}^{\prime}$ dichlorodiphenyltrichloroethane (DDT), its degradation product DDE ( $\mathrm{p}, \mathrm{p}^{\prime}$-dichlorodiphenyldichloroethylene), $\gamma$ hexachlorocyclohexane $(\gamma-\mathrm{HCH})$, also known as Lindane, as well as hexachlorobenzene (HCB). Furthermore, we assessed the seven most frequent PCB congeners PCB 28, PCB 52, PCB 101, PCB 118, PCB 138, PCB 153, and PCB 180.

Sample preparation and residue analyses were carried out in the Research Institute of Wildlife Ecology, University of Veterinary Medicine Vienna. The identification and quantification of the OC compounds were performed using capillary gas chromatography with an electron capture detector after extraction by hexane and a clean-up using deactivated aluminium oxide.
TABLE 1: Amounts of HCB, $\gamma-\mathrm{HCH}$, as well as the $\sum$ DDT per egg $(n=20)$ in ppm.

\begin{tabular}{lccccc}
\hline Egg no. & HCB & $\gamma$-HCH & DDE & DDT & $\sum$ DDT \\
\hline 1 & 0.001 & 0.003 & 0.066 & 0.044 & 0.110 \\
2 & 0.006 & 0.005 & 0.077 & 0.005 & 0.082 \\
3 & 0.004 & 0.001 & 0.066 & 0.000 & 0.066 \\
4 & 0.002 & 0.002 & 0.083 & 0.015 & 0.099 \\
5 & 0.001 & 0.012 & 0.116 & 0.027 & 0.143 \\
6 & 0.001 & 0.002 & 0.120 & 0.003 & 0.124 \\
7 & 0.001 & 0.001 & 0.037 & 0.000 & 0.037 \\
8 & 0.001 & 0.001 & 0.039 & 0.000 & 0.039 \\
9 & 0.001 & 0.004 & 0.094 & 0.001 & 0.095 \\
10 & 0.001 & 0.001 & 0.029 & 0.002 & 0.031 \\
11 & 0.001 & 0.003 & 0.064 & 0.002 & 0.066 \\
12 & 0.000 & 0.001 & 0.012 & 0.000 & 0.012 \\
13 & 0.000 & 0.008 & 0.040 & 0.013 & 0.053 \\
14 & 0.001 & 0.002 & 0.046 & 0.004 & 0.050 \\
15 & 0.001 & 0.001 & 0.046 & 0.008 & 0.054 \\
16 & 0.000 & 0.000 & 0.006 & 0.003 & 0.009 \\
17 & 0.007 & 0.001 & 0.058 & 0.008 & 0.065 \\
18 & 0.001 & 0.001 & 0.037 & 0.008 & 0.046 \\
19 & 0.000 & 0.002 & 0.033 & 0.003 & 0.035 \\
20 & 0.001 & 0.001 & 0.025 & 0.006 & 0.031 \\
\hline & & & & &
\end{tabular}

2.3. Heavy Metals. We tested the content of 14 eggs for lead $(\mathrm{Pb})$, cadmium $(\mathrm{Cd})$, and mercury $(\mathrm{Hg})$. The analyses were carried out by CVUA Freiburg, Germany (State Institute for Chemical and Veterinary Analysis of Food, Dr. O. Fröhlich).

2.4. Statistical Analyses. To compare contamination levels at different developmental stages, we divided the eggs into groups of infertile eggs, fertile eggs with a small embryo where no distinct morphological structures were visible (e.g., feathers or beak), and fertile eggs with a well-developed embryo. We compared the differences between groups with one-way analysis of variance, ANOVA. For post hoc comparison, we used the Holm-Sidak method.

\section{Results}

3.1. Egg Analyses. Of all eggs collected $(n=21)$, more than half $(62 \%)$ contained dead embryos $(n=13)$. This value could not be compared with the embryo mortality rate of the whole colony as some nest sites were inaccessible, and the collection of eggs was not conducted systematically throughout the study period. In 2004, we sampled only two eggs, one of them with a dead embryo. In 2005, we collected 19 eggs, of which 12 contained dead embryos.

3.2. $D D E, D D T$, and $H C B$. Residue values of all eggs examined ( $\left.n=20, \sum \mathrm{DDT}\right)$ varied substantially and ranged from 0.14 to 0.01 parts per million (ppm; Table 1). DDT values of different years could not be compared due to the small sample size in 2004. 


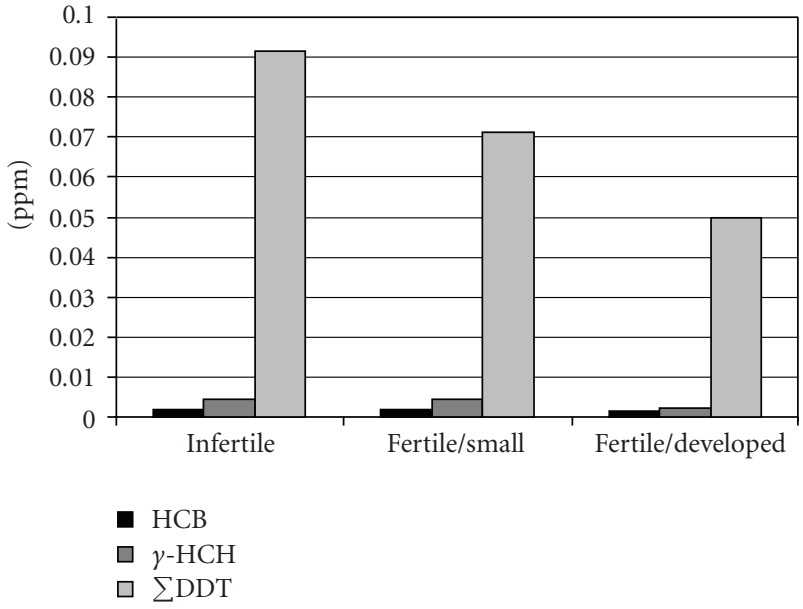

Figure 1: Mean organochlorine values (ppm) in infertile eggs, fertile eggs with small embryos, and fertile eggs with well-developed embryos of Eleonora's Falcon. DDE and DDT are summarised to $\sum$ DDT. Groups differed significantly (ANOVA, $P=.04$ ).

We tested all eggs for HCB, $\gamma$-HCH, DDE, and DDT. $\mathrm{HCB}$ and $\gamma$-HCH were negligible (Table 1 ), and $\sum \mathrm{DDT}$ peaked in two eggs from 2005 (Table 1, no. 5 and 6).

To summarise, eggs were slightly contaminated with DDE and only small amounts of DDT. We also detected traces of $\mathrm{HCB}$ and $\gamma-\mathrm{HCH}$, but only $\sum$ DDT was slightly elevated in four out of 20 eggs (nos. 1, 2, 5, and 6). We, therefore, refer hereafter only to $\sum$ DDT for comparison of the three groups of eggs (infertile, fertile/small, fertile/developed).

3.3. Polychlorinated Biphenyls (PCB). Concentrations of the seven most common and ubiquitous $\mathrm{PCB}$ congeners in the environment were determined (Table 2). The values of $\sum$ PCB levels were not normally distributed, that is, four eggs (no. 1, 4, 5, and 9) were above $0.2 \mathrm{ppm}$, five eggs were around $0.1 \mathrm{ppm}(2,3,6,15$, and 20$)$, and all others $(n=11)$ were below $0.07 \mathrm{ppm}$.

Summarising the results of our PCB analysis, we found a noticeable contamination only with $\mathrm{PCB} 153$ and $\mathrm{PCB}$ 180; the values of other PCBs, however, were negligible. The overall $\sum$ PCB was low in all eggs.

3.4. Comparison of Eggs at Different Developmental Stages $D D T / D D E, H C B$, and $\gamma-H C H$. For comparison of concentrations of $\mathrm{OC}$, we distinguished between three developmental stages in the eggs, which are described in the method section.

Of all OC analysed, the highest concentrations of $\sum$ DDT with a mean of $0.09 \mathrm{ppm}$ were found in infertile eggs, followed by a mean of $0.07 \mathrm{ppm}$ in fertile eggs with small embryos. Finally, the lowest mean of $0.05 \mathrm{ppm}$ was detected in fertile eggs with well-developed embryos (Figure 1).

3.5. Polychlorinated Biphenyls (PCB). We also compared the values of PCB for the three groups (Figure 2). As with $\sum \mathrm{DDT}$, the $\sum \mathrm{PCB}$ was highest in infertile eggs (median

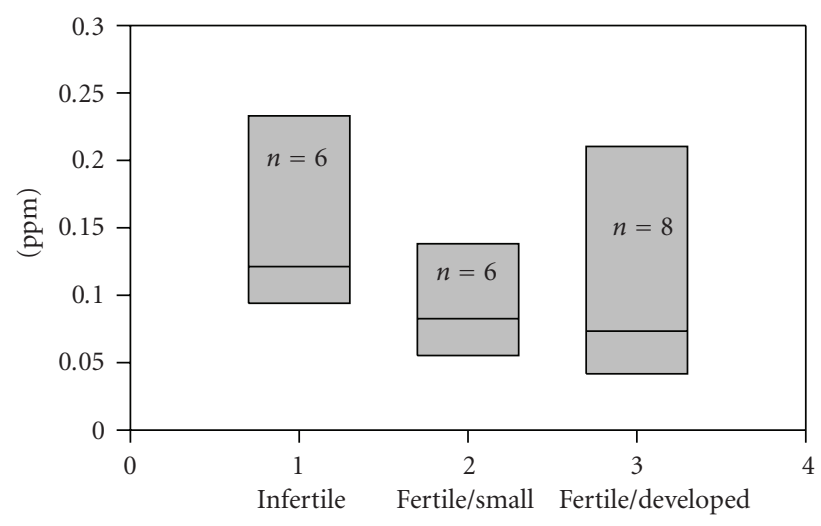

Figure 2: $\sum$ PCB values $(10 \%, 90 \%$ percentiles, and median) in infertile eggs, eggs with small embryos, and eggs with welldeveloped embryos given in ppm; median values are not statistically significant.

$0.12 \mathrm{ppm}$ ), followed by fertile eggs with small embryos (median $0.08 \mathrm{ppm}$ ), and by fertile eggs with well-developed embryos (median $0.07 \mathrm{ppm}$ ).

3.6. Heavy Metals $(\mathrm{Hg}, \mathrm{Cd}, \mathrm{Pb})$. We analysed only 14 eggs for heavy metals. Cadmium $(\mathrm{Cd})$ values were below the detection limit of $<0.005 \mathrm{ppm}$ for all eggs. Mercury $(\mathrm{Hg})$ was present in all of the eggs, but only two had slightly elevated levels. Lead was found in three eggs which were infertile.

3.7. Statistical Comparison of Compounds between the Three Groups. To test for differences of OC contamination, we compared infertile eggs, fertile eggs with small embryos, and fertile eggs with well-developed embryos. The comparison of the three groups revealed a significant difference (ANOVA $\left.F_{2.19}=3.66, P=.05\right)$. Post hoc comparisons supported significant differences between infertile eggs and eggs with well-developed embryos $(t=2.6 ; P=.017)$.

A normality test failed for PCB contamination values. Differences between the median values of the treatment groups were not statistically significant $(P=.454$; KruskalWallis one-way analysis of variance by ranks).

\section{Discussion}

For Eleonora's Falcon, an estimated 10\% of infertile eggs and eggs with dead embryos, and a further $8 \%$ of egg loss due to radiation of the sun are considered normal [8]. In a study of a Moroccan colony of Eleonora's Falcon [2], dead embryos were found in 14 of 32 unhatched eggs, leading to a percentage as high as $44 \%$. As in our study of two Sardinian colonies, the Moroccan rate lies far beyond the average of $18 \%$ determined for Eleonora's Falcon [8]. For other raptor studies, only a few figures are available. A study of the German Sparrowhawk (Accipiter nisus) showed a similarly high embryo mortality of $64 \%$, probably due to the overall amount of toxic substances which an embryo experiences during its development (as compared to $14.5 \%$ dead embryos in Goshawks [9]). Obviously, the rate of dead 
TABLE 2: Polychlorinated biphenyls (PCB) and the sum of all PCB ( $\sum$ PCB) per egg of Eleonora's falcon in ppm.

\begin{tabular}{lcccccccc}
\hline Egg no. & PCB28 & PCB52 & PCB101 & PCB153 & PCB138 & PCB180 & PCB118 & $\sum$ PCB \\
\hline 1 & 0.017 & 0.016 & 0.072 & 0.014 & 0.006 & 0.092 & 0.050 \\
2 & 0.007 & 0.000 & 0.001 & 0.050 & 0.010 & 0.027 & 0.010 & 0.265 \\
3 & 0.007 & 0.004 & 0.002 & 0.048 & 0.004 & 0.054 & 0.003 \\
4 & 0.001 & 0.018 & 0.003 & 0.092 & 0.023 & 0.124 & 0.007 & 0.013 \\
5 & 0.011 & 0.029 & 0.025 & 0.064 & 0.050 & 0.031 & 0.267 \\
6 & 0.008 & 0.002 & 0.001 & 0.042 & 0.010 & 0.046 & 0.005 \\
7 & 0.009 & 0.005 & 0.001 & 0.016 & 0.010 & 0.013 & 0.002 \\
8 & 0.004 & 0.005 & 0.002 & 0.017 & 0.003 & 0.011 & 0.006 \\
9 & 0.001 & 0.002 & 0.003 & 0.100 & 0.033 & 0.099 & 0.010 \\
10 & 0.002 & 0.002 & 0.003 & 0.029 & 0.010 & 0.029 & 0.003 \\
11 & 0.002 & 0.004 & 0.002 & 0.078 & 0.030 & 0.069 & 0.008 \\
12 & 0.001 & 0.003 & 0.002 & 0.001 & 0.002 & 0.004 & not detected \\
13 & 0.004 & not detected & 0.005 & 0.054 & 0.006 & 0.058 & 0.055 \\
14 & 0.008 & 0.005 & 0.001 & 0.017 & 0.011 & 0.018 & 0.003 \\
15 & 0.007 & 0.013 & 0.011 & 0.038 & 0.010 & 0.029 & 0.002 \\
16 & 0.002 & 0.002 & 0.001 & 0.001 & 0.011 & 0.023 & 0.006 \\
17 & 0.002 & 0.002 & 0.001 & 0.018 & 0.003 & 0.011 & 0.001 \\
18 & 0.018 & 0.005 & 0.001 & 0.012 & 0.002 & 0.029 & 0.002 \\
19 & 0.001 & 0.004 & 0.002 & 0.023 & 0.005 & 0.014 & 0.113 \\
20 & 0.004 & 0.005 & 0.001 & 0.038 & 0.003 & 0.049 & 0.047 \\
\hline
\end{tabular}

embryos found in our study is above the average level which is approximately 15-20\% for Eleonora's Falcon [10]. Thus, factors other than "natural" circumstances are likely to play the major role in our findings.

Our study of failed eggs differs from most other such studies by attempting to include the timing of egg failure before or during embryo development. We found that early failure is correlated with the highest values of OC. This supports the results of Prinzinger [11] that contamination with DDE in birds leads to an increase in unfertilised eggs. Although comparatively low, the concentrations of DDE $(0.08 \mathrm{ppm})$ found in infertile Eleonora's Falcons' eggs were twice as high as have been reported in an Italian population of the nonmigratory Eurasian kestrel with levels around 0.04 ppm [12]. In a study of the Barn Owl (Tyto alba) in which birds were fed with low levels of DDE and Dieldrin, DDE was associated with significant embryo mortality and reduced production per pair. The results suggested that DDE had a severe effect on reproduction in wild raptors whereas Dieldrin primarily triggered adult mortality [13].

Our data show an increase in DDE concentrations in Sardinian colonies, although compared to other Eleonora's Falcon colonies in previous years, these values are relatively low, and the different levels of DDE seem to differ substantially. In 1977, a study in Greece [14] revealed DDE values ranging between 0.53 and $4.66 \mathrm{ppm}$ wet weight (corresponding to about 2.64-23.3 ppm dry weight) for 13 eggs, and, in a study of 1990, Wink and colleagues found a mean of DDE of approximately $1.04 \mathrm{ppm}$ wet weight in 14 eggs (this corresponds to about $5.2 \mathrm{mg} / \mathrm{kg}$ dry weight, [15]). These results were well within the range given in a study for a Moroccan colony conducted in 1972 and 1973 based on the residue analysis of 11 eggs [2]: nine eggs showed a DDE load of 1-3 ppm ( 5-15 ppm dry weight), and two had a high content of 20 and 29 ppm wet weight $(\sim 100-145 \mathrm{ppm}$ dry weight). An analysis of contamination in three Eleonora's Falcon eggs on Sardinia in 1996 and 1998 yielded between 0.01 and $0.02 \mathrm{ppm}$ of DDE wet weight (mean $0.02 \mathrm{ppm}$; [16]). Thus, our mean value of DDE from 20 eggs ( $0.05 \mathrm{ppm}$, wet weight) shows a seven-fold increase in DDE load for the same location, although our values are 8-70 times lower than those of a Greek population investigated 30 years ago [14]. Although there is an increasing trend in DDE values for Sardinia, the values found in our study might be too low to exclusively explain such a high percentage of dead embryos.

The PCB concentrations of our study were not very elevated and did not differ significantly between the three groups of eggs $(0.01-0.27 \mathrm{ppm})$. Because in the study of Bianchi et al. [16] different congeners than in our study were investigated, the values cannot be compared. Although, in our study, some PCB (153 and 180) were found more often and in slightly higher concentrations than others, the overall amount of each PCB and the sum of PCB per egg were well within the range of other raptor species ([17-24]). Although few studies have been carried out on the effect of PCB on embryos, we conclude that the overall high percentage of dead embryos found here is not related to the relatively small load of polychlorinated biphenyls.

The analyses of heavy metals of Eleonora's Falcon eggs showed similar levels of lead $(0.31 \mathrm{ppm})$ as in other resident and migratory raptors (e.g., lead $0.16-1.88 \mathrm{ppm}$; [25]) and 
can, therefore, be excluded as the main cause of dead embryos.

Summarising our results we found an overall low contamination load of OC and heavy metals. Despite this, the percentage of dead embryos found here is well above the natural average determined for a colony in Greece [8]. As the sensitivity to this pollutant is species specific and ranges widely [26], we cannot exclude the possibility that Eleonora's Falcons are highly sensitive to DDE. However, despite this potential sensitivity, we find it more probable that the factors that caused the death of the embryos lie outside our analyses. In our study, we refrained from systematic egg collection, that is, taking viable eggs from the eyries during incubation, as the overall population size of Eleonora's Falcon is already small. In conclusion, our results might be biased towards easily accessible nest sites and, therefore, do not mirror the situation of the whole colony. We accepted this potential bias as our goal was to see why the eggs did not hatch and not to define an embryo mortality rate of the Sardinian colonies.

We suggest further data collection and analyses of other contaminants, such as organophosphates (malathion, fenithrotion, etc.) or flame retardants. We also recommend to regularly examine all eggs that remain in the eyries in order to provide more data to determine a general natural rate of dead embryos for the whole population of Eleonora's Falcon.

\section{Acknowledgments}

This paper was funded with grants from the Otto Wolff Foundation to M. Gschweng. F. Spina kindly supported fieldwork in Italy, and the Istituto Nationale Per La Fauna Selvatica "Alessandro Ghigi" (Ozano Emilia) granted permission for ringing and capturing Eleonora's Falcon. The Regione Autonoma Della Sardegna, Assessorato della Difesa dell'Ambiente, Cagliari, granted permission for fieldwork on Sardinia. The LIPU (Lega Italiana Protezione Uccelli) supported fieldwork on San Pietro Island, Sardinia. The authors thank all the volunteers who assisted with the fieldwork from 2003 to 2005, especially those who helped with census and egg collection in 2005: A. Fadda, M. Medda, J. Ploeger, L. Busia, F. Maggia, and M. Grussu. The authors highly appreciate the many useful comments on this paper and good advice during several years of fieldwork by D. Ristow. C. Hoenl conducted chemical analyses at the former Research Institute of Wildlife Ecology, Vienna, Austria, and J. Fietz helped with statistical analyses. A. Cameron corrected the English and made useful comments on a former version of the paper, and M. finn kindly improved the English. All work reported herein was in accordance with ethical standards and guidelines in the care and use of experimental animals of the University of Ulm, Germany. Permission for fieldwork was granted by the Regione della Sardegna, Assessorato della Difesa dell'Ambiente, Cagliari, Sardinia; Prot. 8548 (Autorizzazione ai sensi dell'art. 6, L. R. 23/98Integrazione autorizzazione n8 01/2004 dell 6.08.2004 prot. N. 2730).

\section{References}

[1] A. Dimalexis, S. Xirouchakis, D. Portolou et al., "The status of Eleonora's Falcon (Falco eleonorae) in Greece," Journal of Ornithology, vol. 149, no. 1, pp. 23-30, 2008.

[2] A. L. Clark and D. B. Peakall, "Organochlorine residues in Eleonora's Falcon Falco eleonorae, its eggs and its prey," Ibis, vol. 119, pp. 353-358, 1976.

[3] H. Walter, Eleonora's Falcon. Adaptations to Prey and Habitat in a Social Raptor, The University of Chicago Press, Chicago, Ill, USA, 1979.

[4] M. Gschweng, E. K. V. Kalko, U. Querner, W. Fiedler, and P. Berthold, "All across Africa: highly individual migration routes of Eleonora's falcon," Proceedings of the Royal Society B, vol. 275, no. 1653, pp. 2887-2896, 2008.

[5] S. Hollamby, J. Afema-Azikuru, J. G. Sikarskie et al., "Mercury and persistent organic pollutant concentrations in African fish eagles, Marabou storks, and Nile tilapia in Uganda," Journal of Wildlife Diseases, vol. 40, no. 3, pp. 501-514, 2004.

[6] R. Peveling, A. N. McWilliam, P. Nagel et al., "Impact of locust control on harvester termites and endemic vertebrate predators in Madagascar," Journal of Applied Ecology, vol. 40, no. 4, pp. 729-741, 2003.

[7] A. Fadda and M. Medda, "The colony of Eleonora's Falcon Falco eleonorae in Toro Islet, Sardinia," Aves Ichnusae, vol. 7, pp. 3-21, 2005.

[8] D. Ristow, "International Species Action Plan Eleonora's Falcon Falco eleonorae," European Commission (BirdLife International), 1999.

[9] B. Conrad, "Zur Situation der Pestizidbelastung bei Greifvögeln und Eulen in der Bundesrepublik Deutschland," Ökologie der Vögel, vol. 3, pp. 161-167, 1981.

[10] D. Ristow and M. Wink, "Breeding success and conservation management of Eleonora's Falcon," ICTP Technical Publication, vol. 5, pp. 147-152, 1985.

[11] G. Prinzinger, Ed., Pestizide und Brutbiologie der Vögel, Kilda, Greven, Germany, 1980.

[12] G. Dell'Omo, D. Costantini, J. Wright, S. Casagrande, and R. F. Shore, "PCBs in the eggs of eurasian kestrels indicate exposure to local pollution," Ambio, vol. 37, no. 6, pp. 452-456, 2008.

[13] V. M. Mendenhall, E. E. Klaas, and M. A. R. McLane, "Breeding success of barn owls (Tyto alba) fed low levels of DDE and dieldrin," Archives of Environmental Contamination and Toxicology, vol. 12, no. 2, pp. 235-240, 1983.

[14] D. Ristow, B. Conrad, C. Wink, and M. Wink, "Pesticide residues of failed eggs of Eleonora's falcon Falco eleonorae from an Aegean colony," Ibis, vol. 122, no. 1, pp. 74-76, 1980.

[15] M. Wink, H. Biebach, F. Feldmann et al., "Contribution to the breeding biology of Eleonora's Falcon (Falco eleonorae)," in Proceedings of the Hawk and Trust Conference, pp. 59-72, 1993.

[16] N. Bianchi, C. Leonzio, S. Casini, M. C. Fossi, and S. Focardi, Valutazione dello Stato di Contaminazione nel Falco eleonorae Attraverso l'Utilizzo di Metodologie non Distruttive, Dipartimento di Scienze Ambientali, Università di Siena, Italy, 2003.

[17] M. Weber, W. Fieber, and M. Stubbe, "Persistente chlororganische Verbindungen, Quecksilber und radioaktive Nuklide in Eiern von Rotmilanen (Milvus milvus) aus Sachsen-Anhalt," Journal fur Ornithologie, vol. 139, no. 2, pp. 141-147, 1998.

[18] R. S. Boumphrey, S. J. Harrad, K. C. Jones, and D. Osborn, "Polychlorinated biphenyl congener patterns in tissues from a selection of British birds," Archives of Environmental Contamination and Toxicology, vol. 25, no. 3, pp. 346-352, 1993. 
[19] E. Denker, A. Buthe, H. Knuwer, T. Langgemach, P. Lepom, and I. Ruhling, "Comparison between the burden of xenobiotics in eggs of the Sparrowhawk (Accipiter nisus) from Brandenburg and North-Rhine-Westphalia, Germany," Journal of Ornithology, vol. 142, no. 1, pp. 46-62, 2001.

[20] E. Denker, A. Büthe, D. Glimm, M. Hölker, W. Prünte, and T. Trendelkamp, "Changes in the DDT and PCB burden in life stages of Montagu's (Circus pygargus) and Marsh Harriers (Circus aeruginosus) from North-Rhine Westfalia, Germany," Journal fur Ornithologie, vol. 144, no. 4, pp. 411-417, 2003.

[21] N. Kenntner, Chlororganische Pestizide, polychlorierte Biphenyle und potentiell toxische Schwermetalle in Organproben von Seeadlern und Habichten, Thesis, Humboldt Universität zu Berlin, Institut für Zoo- und Wildtierforschung, Berlin, Germany, 2002.

[22] T. Wiesmüller, P. Sömmer, M. Volland, and B. Schlatterer, "PCDDs/PCDFs, PCBs, and organochlorine pesticides in eggs of Eurasian sparrowhawks (Accipiter nisus), hobbies (Falco subbuteo), and northern goshawks (Accipiter gentilis) collected in the area of Berlin-Brandenburg, Germany," Archives of Environmental Contamination and Toxicology, vol. 42, no. 4, pp. 486-496, 2002.

[23] M. R. Driss, L. Mahmoud, L. Bhari, and M. L. Bouguerra, "Etude préliminaire de la contamination des oeufs de Faucon Pélerin (Falco peregrinus) et Lanier (Falco biarmicus) par les produits organochlorés en Tunisie," Ecological Bulletin, vol. 19, pp. 43-49, 1988.

[24] P. Wegner, G. Kleinstäuber, F. Baum, and F. Schilling, "Longterm investigation of the degree of exposure of German peregrine falcons (Falco peregrinus) to damaging chemicals from the environment," Journal of Ornithology, vol. 146, no. 1, pp. 34-54, 2005.

[25] A. J. García-Fernéndez, J. F. Calvo, E. Martínez-López, P. Maria-Mojica, and J. E. Martínez, "Raptor ecotoxicology in Spain: a review on persistent environmental contaminants," Ambio, vol. 37, no. 6, pp. 432-439, 2008.

[26] J. A. Gervais and D. H. Catlin, "Temporal patterns of DDE in burrowing owl eggs from the Imperial Valley, California," Southwestern Naturalist, vol. 49, no. 4, pp. 509-512, 2004. 

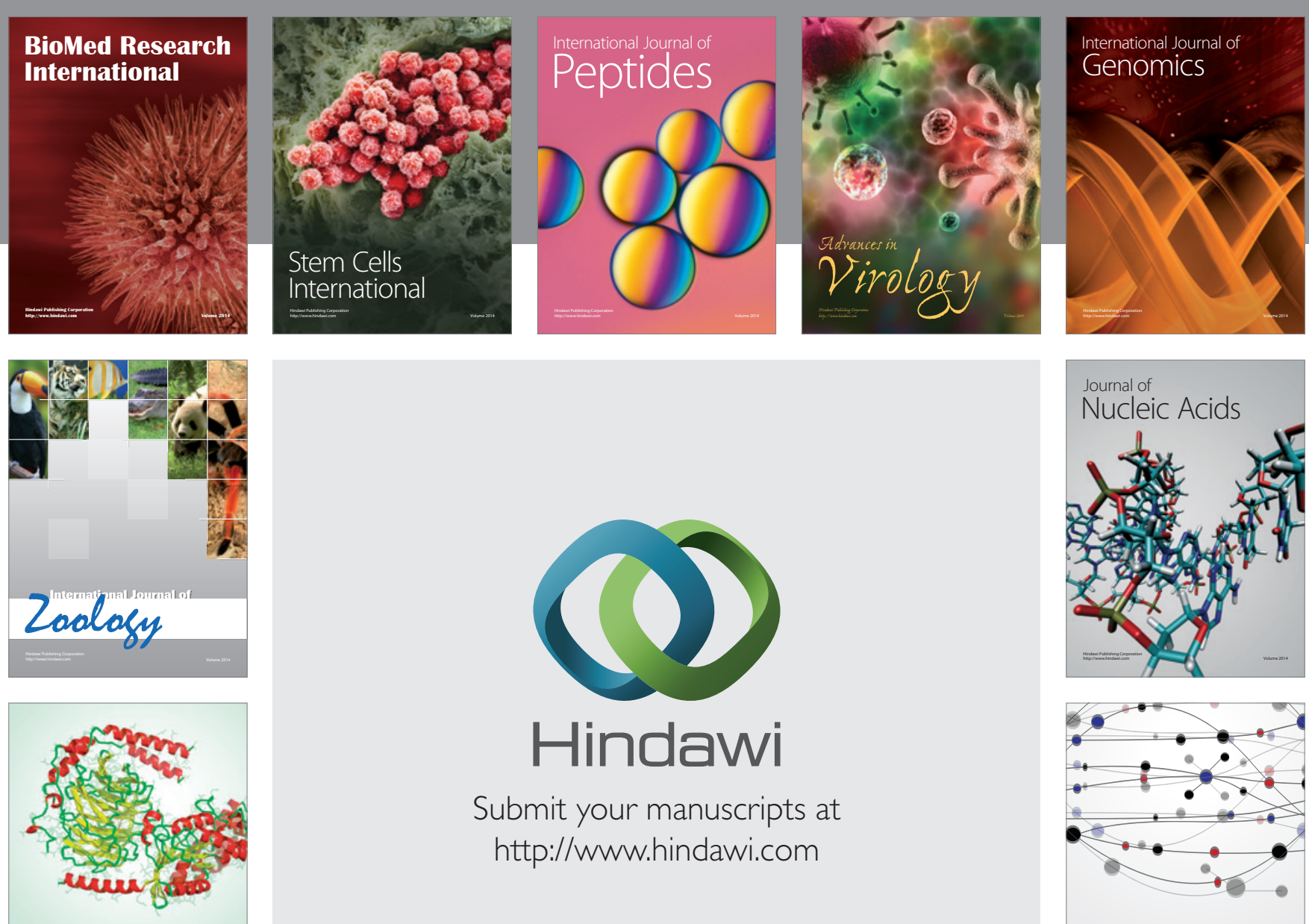

Submit your manuscripts at

http://www.hindawi.com

Signal ${ }^{\text {Jumal }}$ Transduction
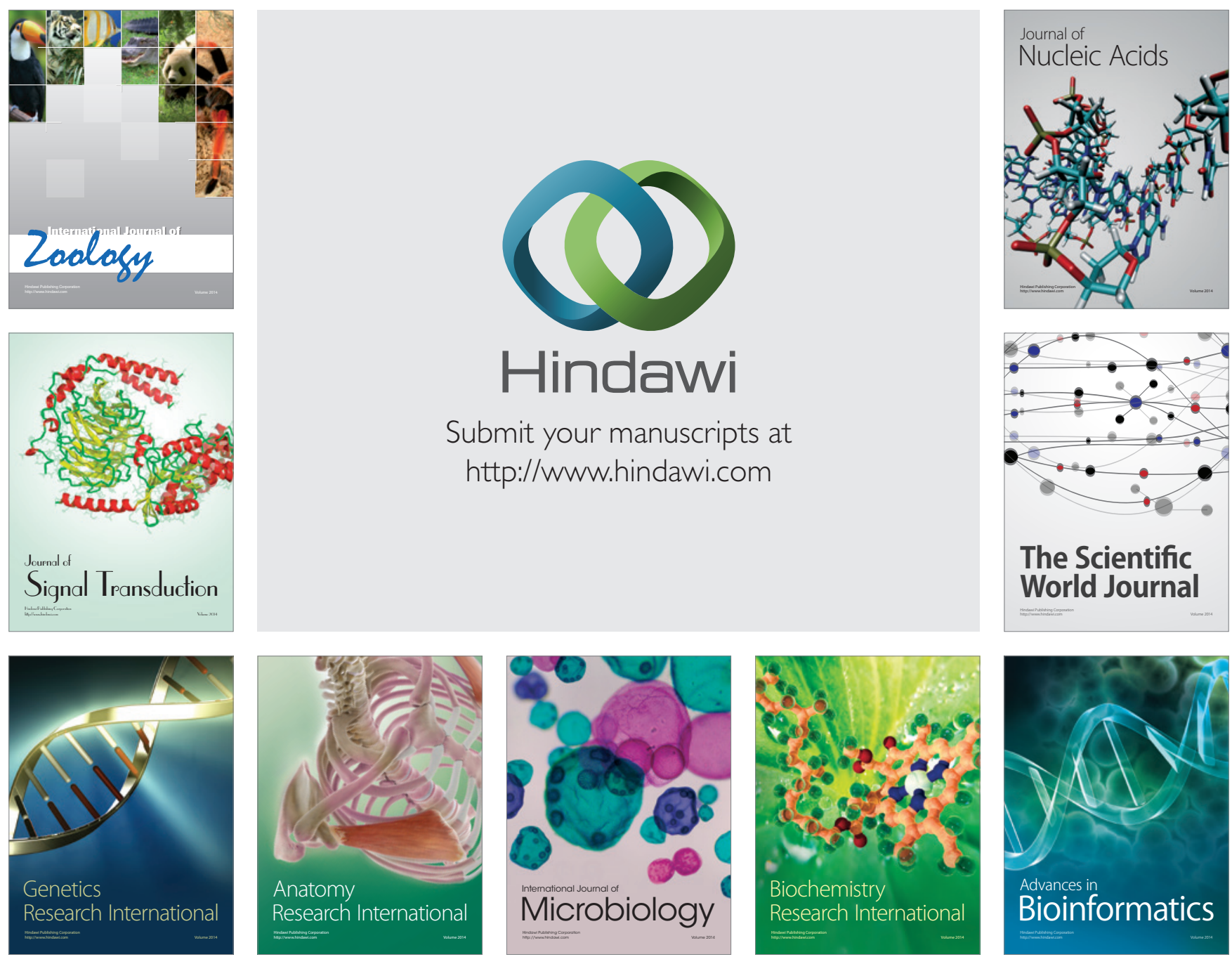

The Scientific World Journal
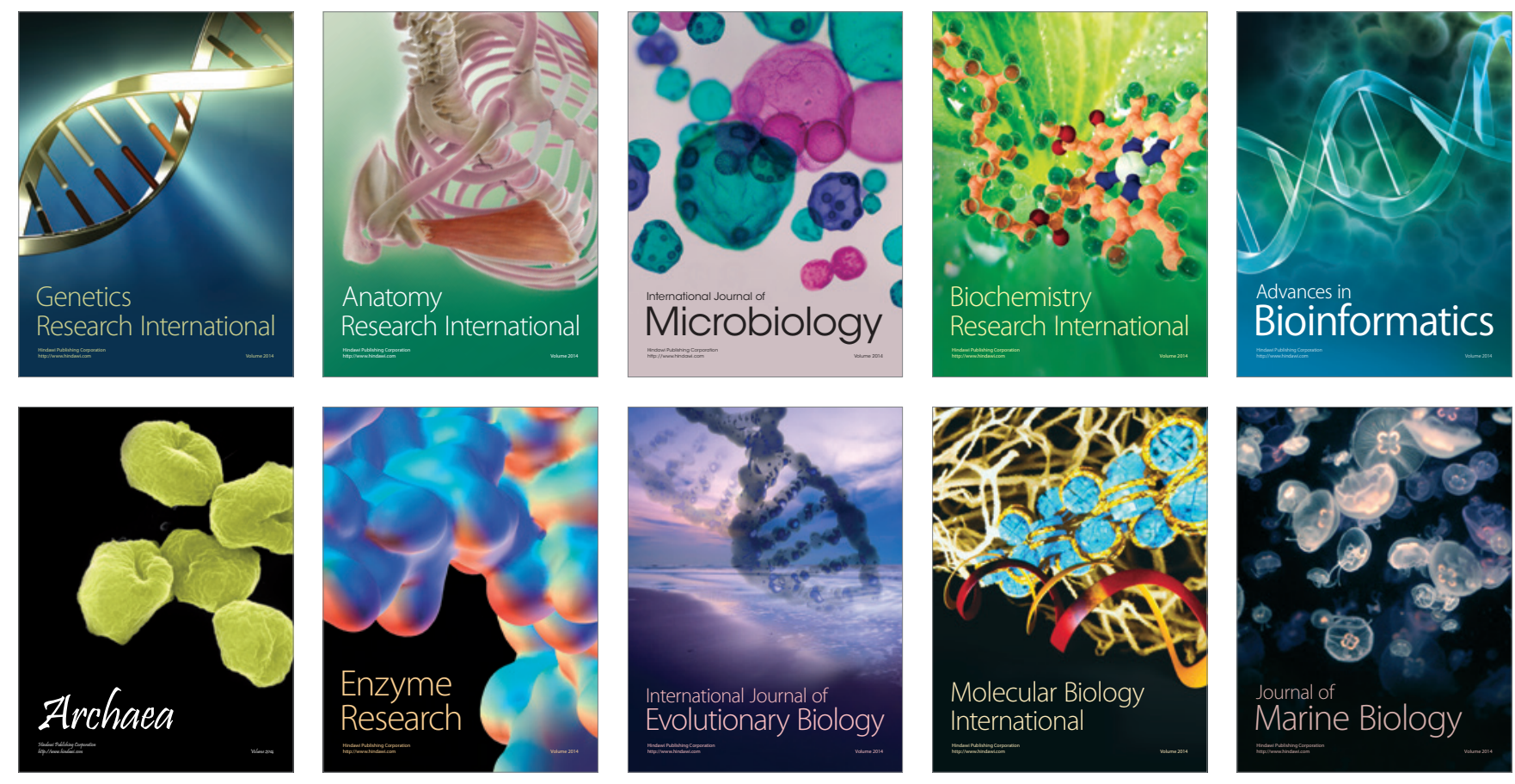